Tér és Társadalom 19. évf. 2005/1. 43-63. p.

Tér és Társadalom

XIX. évf. 2005

$1: 43-63$

\title{
A TURISZTIKAI MILIŐ FÖLDRAJZI ÉRTELMEZÉSE ${ }^{1}$
}

\section{(The Tourist Milieu: an Geographical Approach)}

\section{MICHALKÓ GÁBOR}

Kulcsszavak:

turizmus miliö imázs kultúrtáj mediterrán régió

Annak ellenére, hogy egy célállomás vonzerōinek értékelésekor kézenfekvônek tünik a vizsgált hely miliöjének tárgyalása, a turisztikai milió mégsem tartazik a turizmuselmélet meghonosodott fogalmai közé. Véleményünk szerint a turisztikai miliö a turizmusban hasznosított tér élményelemei megélésének objektív vetülete, vagyis annak a folyamatnak az eredménye, amelynek során az adott helyet felkeresỏ egyének észlelésének lelki eredóje a társadalmi tudás részévé válik. Tehát a turisztikai miliö kapcsán létrejön egy olyan konszenzus, amely a desztinációt felkeresö turistákban kialakult érzelmek közel egységes, informatív visszatiukrözödése. Tanulmányunkban elsösorban arra a kérdésre keressük a választ, milyen tényezök járulnak hozzá egy-egy telepullés turizmusban sikeresen értékesíthetố miliöjének a kialakulasához. Fel kivánjuk tárni, hogy a látogatók által észlelt szubjektiv kép miként objektivizálódik, hogyan válik a társadalmi tudás és a kultúra részévé. Kitérünk a miliö és az intázs sajátos kapcsolatára, ami a hely átélésének és megtapasztalaisának többletéböl fakad. A bemutatísra kerillö, 219 fö véletlenszerï megkérdezésén alapuló vizsgálati eredményekkel meg kivánjuk erösiteni azt a hipotézisünket, miszerint bizonyos területi egységek (e helyütt a Mediterráneum) tekintetében helytálló az egyazon turisztikai miliōhöz való tartozás ténye.

\section{Bevezetés}

Ahogyan az ikrek legtöbbször csak a kívülállók számára tünnek egyformának, úgy abban az esetben sem beszélhetünk két ugyanolyan településröl, ha a tervezésükben, felépítésükben egyazon iskolához tartozó szakemberek vettek részt, vagy a kialakulásukra, fejlödésükre hasonló környezeti tényezők voltak hatással. Az emberekhez közelebb kerülve, a városokban, falvakban több időt eltöltve az első benyomásból eredő felületes véleményalkotás árnyaltabbá válik, és hamarosan jól körülírható egyedi jellegzetességeket fedezhetünk fel. Azonban azok a személyek, akik a munkájukból fakadóan nap mint nap több tucatnyi embertársukkal kerültek közelebbi kapcsolatba, vagy a hivatásuk révén számos, a lakóhelyüktől távolabbi vidékre eljutottak, részesei lehettek egy furcsa érzésnek, amit a neurológiai szakirodalom (Warren-Gash-Zeman 2003) dézsavüként ír le. Sok orvos, tanár számolt be arról az élményéröl, mintha már találkozott volna azzal az illetővel, akit paciensként vagy diákként rábízott a sors, ámbár biztosan tudta, hogy akkor látta életében először. A világot látott emberek pedig azzal szembesủltek, hogy a minden kétséget kizáróan elöször felkeresett településen felmerült bennük egy gyanú, mintha jártak volna már ott. Miként az érintettek számára megfogalmazhatatlan, hogy a felismerni vélt személyek melyik tulajdonságait tartják azonosnak, úgy az is nehezen írható körül, hogy 
egy idegen helyen mi váltja ki az ismert településen tapasztaltak újbóli megélésének érzését. A testfelépítéstöl a frizurán, az öltözeten, a mentalitáson keresztül egészen a kisugárzásig szinte megszámlálhatatlan emberi tulajdonság létezik (ezek együttese a karakter), amelyek összecsengése esetén úgy gondoljuk, valahonnan ismerjük az illetöt. A falvak, városok esetében is tetten érhetőek azok a jellegzetességek, amelyek képesek elhitetni a látogatóval, nem ez az első alkalom, hogy ott tartózkodik.

Tanulmányunkban - a téma újszerủségét tekintetbe vevő átfogó elméleti áttekintést követően - elsősorban arra a kérdésre keressük a választ, milyen tényezök járulnak hozzá egy desztináció turizmusban sikeresen értékesíthetỏ sajátos arculatának, atmoszférájának kialakulásához. Fel kívánjuk tárni, hogy az odalátogatók által észlelt szubjektív kép miként objektíválódik, hogyan válik a társadalmi tudás és a kultúra részévé. Miközben a probléma holisztikus elemzése érdekében bevezetésre kerül a turisztikai miliỏ fogalma, meg kívánjuk erösíteni azt a hipotézisünket, miszerint bizonyos területi egységek tekintetében - ebben a tanulmányban kitüntetetten a Mediterráneumban - helytálló az egyazon turisztikai miliőhöz való tartozás ténye.

\section{A miliö multidiszciplináris megközelítése}

Miliő, az első hallásra archaikusnak tủnő, a francia nyelvből átvett szó eredeti jelentése valaminek a közepe, a mindennapi nyelvhasználatban azonban az embereket körülvevö környezetet értjük alatta. Ha közelebbröl próbáljuk megvizsgálni a kifejezés tartalmát, egy nehezen definiálható, kaleidoszkópikus fogalommal találkozhatunk, amelynek gyökerei a felvilágosodásig nyúlnak vissza, és egészen a 20. század közepéig erőteljes hatással volt a szellemi életre.

Miközben a francia felvilágosodás korának gondolkodói azon fáradoztak, hogy a természettudományok mintájára rátaláljanak az emberi létet, „az általános szellemet" befolyásoló erök racionális voltára, ezt a társadalomfilozófus Montesquieu ${ }^{2}$ az öröklött képességekkel szemben - a klímában lelte meg (Shklar 1994). Késöbb Comte $^{3}$, akit a pozitivizmus megalapítójaként tartanak számon, a klíma szerepében nem kételkedve, azt azonban kevésbé hangsúlyozva a tudomány, a mủvészet, az ipar alkotta „kultúrában” véli felfedezni a miliö eröforrást jelentỏ rendeltetését (Zsigmond 1984). A társadalomtudományokban általánosan elterjedt miliö fogalom Taine ${ }^{4}$ tanaihoz kötődik, aki a szó értelmezésekor az életmód hagyományos mintáinak kialakításában közrejátszó objektív és szubjektív tényezök együttes szerepének fontosságára mutatott rá. Az irodalomtörténet „milieu-elméletként” tartja nyilván Taine hipotézisét, miszerint a mesterek müvészetét befolyásoló tényezök között meghatározó helyet foglal el az alkotókörnyezet (Taine 1881). Taine a nemzeti irodalomra vonatkoztatva úgy véli, hogy az tartalmazza a nép lelkületének és mozgatórugóinak lehető legérzékenyebb megnyilvánulásait is. Véleménye szerint egy adott korban azonos tényezők határozzák meg a társadalom összes kulturális alkotását, ez az írók esetében az öröklött személyiségjegyek mellett a társadalmi, politikai, földrajzi háttérben, valamint a megélt történelmi korban érhető tetten. Durkheim ${ }^{5}$, a francia szociológiai iskola megalapítója a társadalmi miliő szubjektív 
mivoltát hangsúlyozva megkülönbözteti annak külső és belső válfaját, előbbin a közvetlen, utóbbin a távolabbi társadalmi környezetet érti. Durkheim szerint a miliöt emberek és a társadalomhoz tartozó anyagi objektumokban, valamint a korábbi társadalmi tevékenységek eredményeiben (morál, mủvészeti alkotások) testet öltő dolgok építik fel (Durkheim 1978). Scheler ${ }^{6}$, a modern tudásszociológia jelentös képviselöje arra mutat rá, hogy a miliökben körülhatárolt kömyezeti tényezöket az emberi szubjektivitás szempontjából is figyelembe kell venni, mivel a miliőt részleteiben érzékelt környezeti hatásként feltételezi (Scheler 1999). Scheler szerint a miliő annak az összességét jelenti, amit az egyén önmagára hatással lévönek tart. Gurwitsch $^{7}$ a miliőt az egyén megtapasztalásának területeként, a másokkal való együttléte összességeként jeleníti meg, miközben maga a személy is alakul az észleléseiböl levont következtetések által (Embree 2003).

A miliővel kapcsolatos fogalomfejlődést vizsgálva megfigyelhető, hogy a természeti determináció kezdeti túlhangsúlyozásához képest a 20. század közepéig fokozatosan a társadalom szerepe kerül elötérbe, a gondolkodók egyre kevésbé az objektív, sokkal inkább a szubjektív tényezök hatását tartják fontosnak, majd néhány évtizedes visszaesést követöen a társadalomtudományokban a nyolcvanas évektöl éli reneszánszát a fogalom (Hradil 1994).

Deleuze $^{8}$, a filozófiatudomány jeles francia gondolkodójának munkássága a miliö problematikájában ölt testet. Deleuze szerint a miliő olyan köztes-hely (ez a miliỏ szó szerinti fordítása), ami az általa képviselt geometriának megfelelöen nem két dolog, vagy a dolog két szélsö határa között húzódik, hanem egy olyan „,bennfoglaltságban", amelynek egészen egyszerủen hiányoznak a szélei. Tanai értelmezése alapján a miliőként megjelenített közép egyáltalán nem az átlagot, sokkal inkább a dolgok között egy helyhez nem kötődő viszonyt jelöl. A miliök kölcsönösen tartalmazzák egymást, anélkül, hogy bármelyik is határolná a másikat (Moldvay 1997).

A modern szociológia miliőn a heterogén környezeti tényezők azon összefüggéseit érti, amelyeket meghatározható társadalmi csoportok hasznosítanak, és amelyek jól körülírható, jellegzetes életmódok kialakulását vonják maguk után. A miliô nem szinonim a szubkultúrával, mert utóbbi kizárólag olyan szociokulturális tényezőkre irányul, amelyek értékeket, normákat, valamint ezek szimbólumait hordozzák magukon. Az ugyancsak hasonló jelentéstartamú életstílus fogalmát is el kell különíteni, mivel ez alatt a viselkedési szabályszerűségek empirikusan igazolható komplexumát tárgyaljuk, amelyet ugyan befolyásolhat a miliô vagy a szubkultúra, de ezektöl függetlenül döntési, választási és rutinizáló folyamatokon keresztül is kialakulhat (Hradil 1994; Róbert 2000).

A miliővel kapcsolatosan a pszichológia arra mutat rá, hogy az ember környezetének hatásait tudatosan, lelki természetén átszürve éli meg, a környezettel való kölcsönhatásában tehát a lelki élet törvényszerủségei is érvényesülnek. Az emberben ez a lelki miliövetület az összes anyagi, pszichikai és szellemi kömyezetbeli hatás képe, illetve ezek cselekvő feldolgozása. A miliö a kömyezet fontos, kiszürt része, amely egyúttal a legkülönbözöbb érzelmekkel átitatott légkör is. Ismert, hogy az ember egyéni fejlödése annak arányában halad elöre, ahogyan tudatosul benne a 
természeti és társadalmi környezetével való kölcsönhatása. Miközben tehát az egyén a szocializáció folyamatában nap mint nap észleli környezetének elemeit, azokat fokozatosan önmagához tartozónak érzi, gyakran azonosul velük, így ezek a tárgyak, jelenségek a személyiség mélyebb, tudattalan folyamataival is kölcsönhatásba kerülnek (Rókusfalvy 2000).

A miliỏ emberre gyakorolt hatását a neveléstudomány is kutatja. A miliöpedagógia arra törekszik, hogy a lehetö legalaposabban ismerje meg a gyermek személyiségfejlödését befolyásoló külvilág erőit, és a megfigyelés során tapasztaltakat bevonja a nevelés tervszerú rendszerébe. A pedagógia egyes képviselői a családot úgynevezett referenciamiliönek, érték- és mértékadó, társadalmi, természeti összetevőkkel átszőtt környezeti alrendszernek tekintik, amely miközben megszủri a környezeti hatásokat, befolyásolja, módosítja a cselekvést. Mivel a család a gyermeket születésének pillanatától a személyiségfejlödésének meghatározó szakaszában veszi körül, így a leginkább maradandó hatású fejlesztô vagy torzító miliö (Rókusfalvy 2000; Kozma 2001).

A biológia a Föld áttekinthetetlenül változatosnak mondott miliőit az oda beilleszkedett élölények élettereként értelmezi. A legtöbb állat - különösen a magasabb rendủ emlősök - környezete az a felcserélhetetlen miliő, amelyhez specializált szervi felépítésük alkalmazkodott, $s$ amelyen belül az éppolyan fajspecifikus, vele született ösztönmozgások müködnek. Ezzel szemben az ember híján van az állati világhoz hasonló miliö-szeletbe való beilleszkedés kényszerének, mivel nincs olyan miliö, amelyben természetes életképességekkel rendelkezne. Ebben rejlik annak magyarázata, hogy miért nincsenek az embernek földrajzilag természetes és áthághatatlan létezési tartományai. Egyedül az ember képes a világon mindenütt megélni, mert bárhol meg tudja teremteni a lehetőséget arra, hogy a természet helyett egy második természetet készítsen magának, amelyben egzisztálni tud (Gehlen 1976).

\section{A földrajzi miliö alappillérei}

A földrajztudományban tetten érhetö miliöértelmezés megalapozásában kulcsfontosságú szerepet játszott Ritter", akire a modern geográfia alapítójaként egyaránt jelentős hatással volt a már említett francia felvilágosodás és a romantika eszmeisége. Miközben Ritter a geográfiát a többi, különösen a történelemtudomány alapjának tekintette és módszertanában meghatározó hangsúlyt helyezett a szintetizálásra, filozófiai igényességgel bástyázta körül a korábbi századokban is ismert földrajzi determinizmus gondolatvilágát (Vinkovics 1983). Ritter szerint a geológiailag megalapozott táj filozófiai tartalmában az individualitást képviseli, az általánosan ható természeti törvények egy konkrét képzödményt hoznak létre, így a táj mint individuum véges számú jelenség egysége. Ritter tanai a geológiai belsőt állítják a középpontba, a felszínt csak a külső megjelenésként értelmezik. Éppen ebből ered a földrajzi determinizmus ${ }^{10}$, miszerint az előzetesen fennálló okok teljesen meghatároznak minden eseményt és kizárják a szabad akaratot, az emberi cselekvés viselkedési szokások és bizonyos külső erök eredőjének tekinthető. 
Az emberföldrajz tudományos megalapozásában elvitathatatlan érdemeket szerzett Ratzel ${ }^{11}$ szerint is szoros összefüggés van az egyes embercsoportok jellemzői és azon területi egységek között, ahol élnek és fejlödnek. Miközben a fizikai környezetnek az egyénre és a társadalomra gyakorolt hatásáról értekezik, megállapítja, hogy az éghajlat jelentős hatással van az úgynevezett „müveltségi övek” kialakulásában (Ratzel 1887). Mivel az addigi világtörténelem érdemi fejleményei a mérsékelt éghajlati zónában játszódtak le, ezért ezt tekinti az ,igazi” müveltségi övnek. Megitélése szerint a nemzeti jellemre is hatással van a természet, így a vad, zord táj búskomorságot vált ki az ott élő társadalomból. Ebből kiindulva a képzőművészetről való értekezése során egészen odáig megy, hogy a népek mủveltségét a festészetben megjelenỏ színvilággal hozza összefüggésbe. Tekintettel arra, hogy Ratzel zoológiából szerzett diplomát (Hajdú 1998), így a faunára vonatkozó ismeretei, a földrajzi miliőnek az állatvilág élettereként való értelmezése minden bizonnyal hatással volt az „Anthropogeographie”-ben megfogalmazott, a természeti tényezök túlzó egyoldalúságát hangsúlyozó determinizmusára.

A 20. század első évtizedeinek gondolkodói között már megjelenik a miliőelmélet földrajzi aspektusú kritikai megközelítése. Dékány' ${ }^{12}$ szociológusként az abszolút szabadság gondolatával felelteti meg a miliő determináló szerepét, véleménye szerint sem egyik, sem másik nem tekinthetö célravezetö kutatási hipotézisnek. Sajnálatát fejezi ki, hogy Taine a miliö fogalmát ,masszásította”, miközben öt megelözően Comte már a valósághoz közelebb állóan, többes számot használva miliökröl értekezett (Dékány 1921). Ratzel érdemeit elismerve kifejti, hogy a német geográfus munkássága minden nemü konkrétságot nélkülöz, azaz érdemi tájkutatás nélkül igyekszik a miliő szerepének egyoldalúságát hangsúlyozni, miközben megfeledkezik a kölcsönhatások tényéröl.

Mendöl ${ }^{13}$ szerint a térben és időben mennyiségileg és minőségileg különböző mértékben szintetizálódó tájjelenségek alkotják a miliőt, a táj mozgásjelenségei képezik azokat a miliőhatásokat, amelyek befolyásolják az ember életét. Ezek közül Mendöl is a klíma élettani hatásait tartja elsődlegesnek, determinizmusa abban érhetô tetten, hogy a táj benépesülésében kizárólagos szerepet tulajdonít a miliönek. Összefüggésbe hozza a miliőt az ember mủveltségszintjével, ami a kultúrtáj képében tükrözỏdik vissza. Az egyén éppen a mủveltségszint növekedésének köszönhetően képes megszürni, módosított formában érezni a miliö fiziológiai és lelki formálóerejét. Annak ellenére, hogy Mendöl nem érinti a turizmus témáját, olyan alapvető elemeit fogalmazza meg a turisztikai miliőnek, amely előrevetíti annak fogalmi létjogosultságát: „A miliỏ közvetlen hatása pszichológiai értelemben is megnyilvánulhat. A táj forma-, szín- és szagkomplexusa, hő- és egyéb klimatikus hatásai, az idỏjárási jelenségek ingadozásának mértéke mint tiszta érzéki benyomások folytonosságuknál fogva kétségtelenül nem maradhatnak lelki hatás nélkül." (Mendöl 1932, 35).

A földrajzi környezet értelmezésének kiterjesztése során a tradicionális, természeti és ember alkotta elemekre koncentráló megközelítés mellett bevezetésre került az úgynevezett megélt környezet fogalma is (Kirk 1963). Az észlelhetö környezet 
(phenomenal environment) az érintetlen és az emberi beavatkozás következményeként átalakult természetet, valamint pusztán a társadalmi tevékenység által létrehozott tárgyiasult valóságot foglalja magában, míg a megélt környezet (behaviour environment) bonyolult pszichológiai folyamatok mentális leképezödése. A megélt környezet az objektív valóság szubjektív észlelése, amelyet az impressziók hoznak létre. Amíg az észlelhető környezet leképeződése egy viszonylag egyszerü fizikai transzformáció eredménye, történetesen az érzékszerveink által befogadott és feldolgozott ingerek megjelenése, addig az esetek többségében az ennél szükebb terjedelmü, kevésbé részletgazdag megélt környezet, ahogyan az észlelhető környezetet érzékeljük, társadalmilag és kulturálisan erősen befolyásolt. Ugyanazt az észlelhető környezetet másképp éli meg két különbözö történelmi tradíciókkal, kulturális háttérrel, értékorientációval rendelkező ember.

A miliő modern, egyetemlegesnek tekinthető földrajzi értelmezésében olyan szférát jelöl, amelyben az egyén élete zajlik, és amely egyúttal hatással van annak személyiségére (Mayhew 1997). Ez a szféra egyrészt magában foglal valós tárgyakat és embereket, másrészt bizonyos társadalmi és kulturális jelenségeket, valamint azokat a képzeteket, amelyek befolyásolják az egyén magatartását. Mindent egybevetve, a szélesen értelmezhető észlelhetö környezet az egyén szociokulturális értékrendszerén átszủrve válik megélt, a miliö alapjául szolgáló környezetté (Small-Witherick 1989). A kapcsolat természetesen nem egyirányú, mivel a kölcsönös összefüggések hálózataként, egyfajta viszonyrendszerként definiálható megélt környezet tapasztalása során az emberek egyéni válaszokat adnak, vagy irányítottan viselkednek, és ez visszahat az észlelhető környezetre (Clark 1985).

\section{A turisztikai miliö komplex problematikája}

\section{A turisztikai miliő definiálásának nehézségei}

Annak ellenére, hogy egy turisztikai célállomás bemutatásakor, vonzeröinek, környezetének értékelésekor kézenfekvőnek tünik a vizsgált hely miliöjének tárgyalása, a turisztikai miliö mégsem szerepel a turizmuselmélet bevett fogalmai között. E hiátus oka abban keresendő, hogy a miliő turizmus-orientációjú definiálására éppen a töle elválaszthatatlan élményszerzés bonyolult pszichológiai megközelítése miatt (Csíkszentmihályi 1998; Maslow 2003) eddig csak érintőlegesen vállalkoztak. Tekintettel arra, hogy a turizmus lényegéről a lakókörnyezetünket és a mindennapi térpályáinkat elhagyó, élményszerzéssel párosuló környezetváltozásként gondolkodunk (Michalkó 2004), ezért a turisztikai miliö értelmezésében is elsődleges fontosságot tulajdonítunk az élményként kódolódó ingerek megjelenésének. Ugyanakkor a befogadó szerepét betöltỏ turista szubjektuma mellett nem szabad megfeledkeznünk arról sem, hogy a miliö magából a felkeresett hely környezetéböl fakad, tehát az objektív valóságtól el választhatatlan.

Mindezekre tekintettel felállíthatunk egy munkadefiníciót, miszerint a turisztikai miliö a turizmusban hasznosított tér élményelemei megélésének objektív vetülete, 
vagyis annak a folyamatnak az eredménye, amelynek során az adott helyet felkereső egyének észlelésének lelki eredője a társadalmi tudás részévé válik. Tehát a turisztikai miliő kapcsán létrejön egy olyan konszenzus, amely a desztinációt felkereső turistákban kialakult érzékletek és érzelmek közel egységes, informatív visszatükrözödése.

A turisztikai miliő a tér relativitásának és szimbolikus mivoltának erősítéséhez, mintsem abszolút és anyagi jellemzöinek alátámasztásához járul hozzá. A térhez kötődő asszociációk miatt a miliö kapcsán a célállomás földrajzi adottságainak érzelmi vetületei kerülnek előtérbe. Mivel a földrajzi hely turisztikai interpretációja során a táj az ábrázolás egy formájává válik, és fokozatosan megszünik objektív tapasztalati tárgy lenni, a marketing révén megjelenített miliőelemek egy idỏ után részévé válnak a helyiek identitásának is (Pritchard-Morgan 2001).

A turisztikai miliő a már említett kaleidoszkópikus összetettsége és az emberi tényezőktöl való nagyfokú függése miatt nem tekinthető statikus fogalomnak, azonban a turizmuselméletbe történő sikeres bevezetéséhez elengedhetetlen a nómenklatúrában történő elhelyezése.

\section{A turisztikai miliö helye a turizmus rendszerében}

Annak ellenére, hogy a turisztikai miliő az érzékletek sajátos interpretációjaként körvonalazódik, vagyis elválaszthatatlan a kereslettől, kialakulása mégis a turisták által látogatott hely kínálatából fakad. Így a turisztikai miliőnek a turizmus rendszerében való elhelyezkedése a piac kínálati oldalához köthetö, de kiformálódásában az egyes környezeti elemekre is komoly szerep hárul. A turizmus helyi feltételei alatt tárgyalt fogadókészség és fogadóképesség tényezöi, különösen a helyi lakosság és a vállalkozói szféra turistákkal szembeni attitüdje, a tárgyi kondíciókhoz tartozó alap-infrastruktúra, továbbá az idegenforgalmi infra- és szuprastruktúra jellegzetességei jelentős mértékben meghatározhatják egy hely miliőjének mibenlétét. A vendégszeretet különböző szintjei, a szolgáltatók magatartásának összetevöi, a közlekedési, a közüzemi és a kommunikációs hálózatok állapota ugyanúgy miliőformáló tényező, mint a vonzerők feltárását segítő létesítmények, vagy a szállodák, éttermek, kiskereskedelmi egységek formavilága. Mindemellett a piacot övező társadalmi, gazdasági, politikai, technológiai és természeti környezet is részévé válhat a turisztikai miliőnek, különösen azokban az esetekben, amikor ezek az elemek dominánssá válnak. Mégis talán a társadalmi környezet játszik legintenzívebben közre a turisztikai desztináció miliöjének kialakulásában, mivel a helyi lakosság demográfiai, ökonómiai helyzete, kulturális felkészültsége, életmódja, értékrendszere, hagyományai, az ezekből fakadó egyéni és közősségi viselkedésformák olyan sajátos atmoszférát alkotnak, amely akár önmagában is kiválthatja a turisták érdeklödését, ennél fogva a turisztikai miliỏ egyes esetekben vonzerővé válik. Ha a turizmus rendszerében egy-egy környezeti tényezö túlterjed, az visszavonhatatlanul rányomja bélyegét a miliőre. Például egy turisztikailag vonzó, ugyanakkor politikailag instabil hely, ahol a pártok küzdelme folyamatosan az utcán zajlik, plakátrengeteggé és nagygyưlések színterévé alakíthatja a környezetet, és azt sugallhatja, hogy ott a 
miliő szerves része a politika. A gazdaság számos eleme tetten érhető a miliőben, azonban egy tartós infláció (az árcédulákon szereplö nullák vagy a nap mint nap változó árak) olyan élménnyé konvertálódhat, amely a hely miliőalkotó sajátosságaként él majd tovább. A technológiai környezetben különösen a közlekedési eszközök világa, a természeti környezetben a flóra és fauna egyedei vagy társulásai képezhetnek túltengö miliöelemeket. Minderre figyelemmel a turisztikai miliöt a rendszer olyan köztes szintjeként értelmezhetjük, amely egyrészt a kínálatot megtestesítő turisztikai termékből és annak környezetéböl fakad, másrészt a turisták észlelése által ölt valódi testet.

\section{A kultúrtáj és a turisztikai miliö kapcsolata}

A turisztikai miliö kialakításában elengedhetetlen szerepet kap a természeti környezet arculatát megváltoztató társadalom, így az adott térben éló lakosság tájformáló hatása visszatükröződik a turisták által felkeresett hely élményapparátusában. Ha, például falusi vagy városi miliőkről beszélünk, akkor minden esetben a kultúrtáj (Berényi 2001) azon elemeinek sokaságát idézzük fel, amelyek ezeket a tereket általánosságban jellemzik: a falut az agrárterületek és az alacsony építésü házak dominanciája, a település nyugalma, a házialllatok ricsaja, a mezögazdasági termelésből fakadó szagok, a ráéró, kíváncsiskodó emberek világa, a várost ezzel ellentétben nagyfokú beépítettsége, forgataga, a közlekedési eszközök bủze, a mindig rohanó, a világtól elforduló emberek testesítik meg. A desztináció turisztikai miliöjének lényege éppen abban keresendő, hogy az elsö, legtöbb esetben a fizikai arculat észleléséből fakadó képeken túlmenően olyan egyedi jellegzetességeket is magán hordoz, amelyek az ott élök történelméből, kultúrájából fakadnak, és meghatározó mértékben befolyásolják a turisták élményeit.

Ebböl eredöen egy osztrák alpesi falucska miliöjének egy magyar alföldi faluéval történő összehasonlításakor - annak ellenére, hogy a társadalmi munkamegosztásban hasonló funkciót töltenek be - igencsak eltéró jegyek körvonalazódnak. Természetesen a városi terek miliőként való értelmezésében is komoly szerepet kap a társadalmi hatás (Puczkó-Rátz 1998). Egy nagyváros ritkán képez összefüggő, egységes turisztikai miliőt, sokkal inkább csak kulisszái vannak, amelyekböl a látogató különböző élményelemeket merít. Szzijártó (2004) a városi kulisszákat olyan sajátos nyilvánosságformaként írja le, amelyekben az ott élő csoportok egykor viszonylagos homogenitással és magas fokú belsö kommunikációval rendelkeztek, a miliőhöz való tartozás jele pedig a városi térben elfoglalt meghatározott hely volt. Ez napjainkra az individualizációs folyamatoknak köszönhetỏen átalakulóban van, a városok kulisszái mára csekély térbeli kiterjedéssel bírnak és idöben korlátozott kontaktust tesznek lehetővé. Szijártó szerint a kulisszák olyan ,projekciós felületek”, amelyeken érzések, vágyak, fantáziák jelennek meg. A nagyvárosok életében üde színfoltot képviselnek azok a városrészek, amelyek az oda bevándorlók etnikai alapú szegregációjából (FischerParnreiter 2002) fakadó életterekként jelennek meg. A metropoliszok kínai, olasz 
vagy éppen zsidó negyedei egytöl egyig magukon hordozzák azokat a turisztikai miliőelemeket, amelyek az ott élök anyaországának településeit jellemzik.

Ahogyan a kultúrtáj folyamatos változásokon, átalakulásokon megy keresztül, úgy a turisztikai desztinációk bizonyos miliöelemei sem stabilak. A tradicionális miliőelemek erodálásában a falvakat az egyik oldalról érintő szuburbanizáció (Dövényi-Kovács 1999), dzsentrifikáció (Phillips 1993), a másik oldalról tetten érhetô elvándorlás (Illés 2000) és inkább a nagyvárosokban jelentkező globalizációs (Erdösi 2003a; 2003b), revitalizációs (Meyer 2001) jelenségek játszanak közre. A falvak elnéptelenedésével vagy éppen elövárosokká válásával, a mezőgazdaságot háttérbe szorító modernizációjával pontosan azok a miliőelemek tünnek el, amelyek korábban az odalátogató vendégek körében vonzóak voltak. A nagyvárosoknak a világvárosokra jellemző globális modellekhez való igazodása, a slummosodó városrészek életrekeltése pedig feloldja az egyediségükből áradó atmoszférájukat.

A miliő és a kultúrtáj kapcsolatának talán legizgalmasabb és e helyen csak a felvetés szintjén körvonalazódó kérdése, vajon egy ismert miliöapparátusból bármely térségben létrehozható, felépíthetö-e egy olyan objektum (színtér), amely képes az eredeti miliőben való megmártózás illúzióját kelteni? Képessé tehető egy terület arra, hogy azt sugallja, a vendég valóban abban a környezetben jár, amelynek élményelemeivel szembesül. Véleményünk szerint a szóba jöhető skanzenek, Disneyland típusú tematikus parkok csak díszletként szolgálhatnának egy ilyen vállalkozásban, ha nem sikerül valódi élettel megtölteni őket, akkor még a miliő csírái sem ültethetők át.

\section{A turisztikai miliö társadalmi vetületei}

Egy adott turisztikai desztináció miliőjébe beleívódnak a helyi társadalom szociokulturális sajátosságai, így azok tipikus jegyei visszatükröződnek a turisták élményeiben (Fülemile 1998; Szarvas 1998). A nemzetek jellemvonásainak térelemekben való továbbélése a turisztikai miliő része. Ez gyakran nem más, mint az adott nemzettel kapcsolatos kulturális sztereotípiának, a nemzetkarakterológiának a turisták által életre keltett vetülete. Hunyadi (1996; 2003) számos munkájában arról számol be, hogy egy nemzethez tartozó egyének feltételezett viselkedéséröl viszonylag jól körülhatárolható kép él a többi nemzet polgárainak fejében. Ezek a sztereotip képek persze akkor is bevésődnek, ha történetesen soha sem találkoztak az adott országbeliekkel. A probléma kapcsán elsősorban azokra a jellemvonásokra kell koncentrálnunk, amelyek a turistáknak a helyi lakossággal való közvetlen kontaktusa révén kerülnek felidézésre, illetve átélésre. Ez azoknál a társadalmaknál, amelyek az „utcán” élnek anélkül is megvalósulhat, hogy bárminemú szolgáltatói szituáció is létrejönne. Az extravertált hétköznapi élet köztéri epizódjai (egymás önfeledt üdvözlése, a magánárusítás, a játék, a száradó ruhák látványa stb.) kívülállóként is mély nyomot hagynak a látogatókban, ahogy az is az élmény részévé válik, amikor zárkózott emberek képezik a társadalmi környezetet. Természetesen a klasszikus vendég-vendéglátói kapcsolat során az átlagosnál autentikusabb információk raktározódnak el a helyiekröl. A vásárlás, a vendéglöi fogyasztás, a külön- 
bözö attrakciók felkeresése alkalmat biztosít a lakossággal való személyes találkozásra. Mivel a sztereotípiának éppen az a lényege, hogy leegyszerüsítse a megismerés amúgy bonyolult folyamatát, a látogatók hajlamosak arra, hogy egy-egy szituációban saját sztereotípiáik visszaigazolását lássák.

Nem szabad megfeledkeznünk arról, hogy a miliö észlelését erősen befolyásolja a befogadó személye. Amennyire a turisztikai magatartás személyfüggö, úgy a hely megélésében is közrejátszanak a látogató egzisztenciális és szociokulturális sajátosságai (Pizam-Sussmann 1995). A helyi lakossággal való kommunikáció mértéke, a helyismeret, a tér által kínált tevékenységekben való részvétel intenzitása, az attitüd egytölegyig befolyásolják a desztináció társadalomból fakadó miliőelemeinek megélését. A más-más kultúrkörnyezetböl érkezö turistacsoportok miliöértelmezései visszahathatnak magára a miliőre, amely leginkább a marketingkommunikációban testet öltő imázsformálás révén valósulhat meg. Egy-egy elemnek a célpiac észlelésének megfeleltetett kiemelése torzíthatja az adott desztináció turisztikai miliōjét.

\section{A turisztikai miliö és az imázs}

A turisztikai miliö imázzsal meglévő sajátos kapcsolata abban fejezhetö ki, hogy elöbbi kialakulásához nélkülözhetetlen a hellyel kialakítandó személyes kontaktus, vagyis a célállomás felkeresése, utóbbi azonban képes úgy is a fejekben élni, hogy bármilyen szubjektív benyomás érte volna az egyént. A miliő és az imázs egyaránt tartalmaz objektív és szubjektív elemeket, mindkettö esetében fennáll a kollektív tudás ténye, de a miliő az előzetesen kialakított imázs, a prospektusok diktálta várakozások tényleges megéléséböl építkezik, sokkal színesebb, a személyes tapasztalatok révén árnyaltabb fogalom. Az imázs, ahogy a neve is mutatja egy kép, melynek kialakulásában a különböző szocializációs közegek vesznek részt, nem szükségszerủen tartalmaz olyan érzelmi elemeket mint a miliö. A turisztikai miliö sokszor az imázs megfeleltetése a ténylegesen átélt, megtapasztalt, értékelésen átesett valóság. Amíg az imázs lehet negatív, addig a turisztikai miliő inkább pozitív fogalom. A turisztikai miliő eltérhet az előzetesen elvárt imázstól, azt utólagosan alakíthatja. A desztináció-imázs elsősorban az utazási szokások, a miliő a turisztikai magatartás befolyásolásában játszik kiemelkedő szerepet. A turisztikai imázs is rendkívül mozaikos tényező, amely magában foglalja a potenciális turistáknak a desztinációra vonatkozó hiedelmeit, elképzeléseit, de benne a benyomások kisebb mértékben játszanak szerepet. A turisták tudatában létrejövő imázs objektív tényszerüségéhez a média jelentősen hozzájárul. A miliőről való gondolkodás kapcsán éppen az imázzsal kapcsolatosan merül fel egy újabb, ebben a tanulmányban nyitva maradó kérdés, vajon mennyire járulnak maguk a turisták hozzá, hogy létrejöjjön az adott desztináció turisztikai miliője, az milyen mértékben tekinthető a turisták imázsból fakadó szükségleteit kielégítő kreálmánynak? 


\section{Egy turisztikai desztináció miliöjének elemei}

Egy adott hely turisztikai miliője bemutatásának összetettségét a kedvenc étterem leírásához hasonlíthatjuk, melynek kapcsán nehezen vehetök számba azok a tényezők, amelyek alapján összeáll a törzsvendég végsö benyomása. Felmerül a kérdés, mit találnak az emberek vonzónak a gyakran látogatott vendéglátóhelyen? Az árat, az adagot, az ízeket, a választékot, az étlap ötletességét, az asztalok elrendezését, a dekorációt, a bútorokat, a zenét, az állandó duruzsolást vagy éppen a meghitt nyugalmat, a falakat, a közönséget, a fekvését, a szagokat, a pincérek viselkedését, esetleg mindezt együttvéve, ez adja azt a megfogalmazhatatlan atmoszférát, amelyet egy étterem sugároz. Ebböl kiindulva a miliő idegenforgalmi szempontú kutatásánál elsődlegesnek tartjuk, hogy megpróbáljuk összegyüjteni és kategorizálni a célállomás mindazon elemeit, amelyek meghatározó mértékben hatnak annak atmoszférájára, ezáltal a vendég turisztikai magatartására.

A turisztikai miliő a desztináció kínálatának egyfajta metaszintjeként értelmezhető. Eszerint tartalmazza mindazon kínálati elemeket, amelyek a hely rutinszerü fogyasztása során kézzelfogható tárgyi valóságnál absztraktabbak. A turisztikai miliỏ egyes elemeit a legtöbb turista nyilvánvalóan észleli, de azok a megfoghatatlanság érzését gerjesztve csak együttesen képesek a látogatókból kötődést vagy taszítást kiváltani. Elöfordulhat, hogy nem tudatosul a hely turisztikai miliöjének ténye a turistákban. Ennek oka a tartózkodás rövid idötartamában vagy a desztináció jellegtelenségében keresendő. Ott, ahol tetten érhető a turisztikai miliö „varázsa”, az l. ábrán szereplö tényezők többségének konstellációja mutatható ki.

\section{1. ÁBRA}

A turisztikai miliö kaleidoszkópikus felépitése (Kaleodoscopical Structure of the Tourist Milieu)

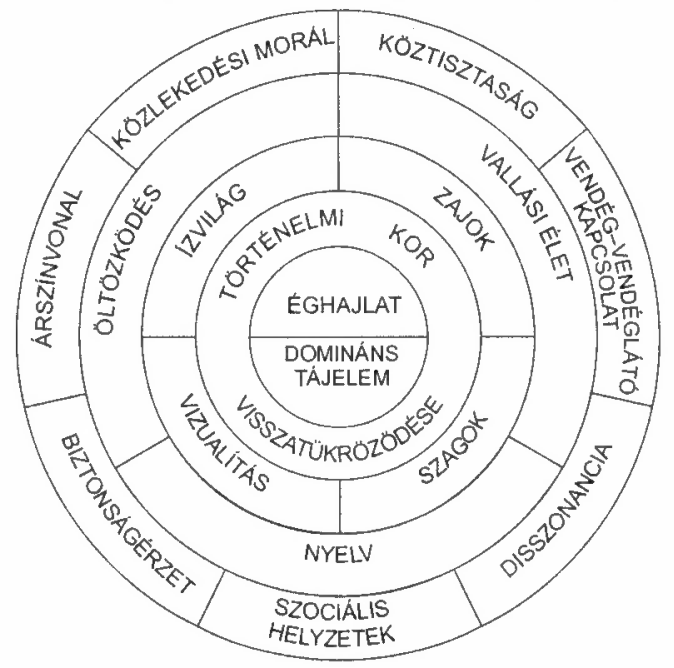

Forrás: Saját szerkesztés. 
Ahogyan a bevezetőben felvetett hipotézisben megfogalmaztuk, egy-egy desztináció turisztikai miliője - feltételezhetöen a hasonló földrajzi fekvésnek és/vagy kulturális háttérnek köszönhetően - nagyobb területi kiterjedésben is megtalálható. A turisztikai miliő ugyan korlátozódhat egy településre, lehet régió- vagy ország-specifikus, de egyes esetekben több ország vonatkozásában is kimutathatóak bizonyos azonosságok. Véleményünk szerint a turisztikai miliők között a mediterrán és az arab miliő rendelkezik azokkal az építőelemekkel, amelyek relációjában annak ellenére, hogy különböző országokban vizsgálódunk, számos egyezéssel találkozunk. Gyakorlati megközelítésben ez azt jelenti, ha képzeletben eltüntetjük az összehasonlításban részt vevő térségek közismert attrakcióit, és a miliöelemekre csupaszítjuk a desztinációikat, akkor könnyen összetéveszthetővé válnak az érintett országok.

\section{A mediterrán turisztikai miliö társadalmi konstrukciója Magyarországon}

\section{A vizsgálat módszertana}

Annak érdekében, hogy empirikus vizsgálati eredményekkel támaszthassuk alá az általunk kiválasztott típus, történetesen a mediterrán turisztikai miliő kiterjedt létezését, 2004 tavaszán a turizmus kutatásmódszertanában is ,pilot projektként” ismert (Ryan 1998) felmérés keretében kérdöíves megkérdezést végeztünk a Kodolányi János Föiskolán. Arra kértük a vizsgálatban részt vevő föiskolai hallgatókat, hogy a kérdezőbiztos szerepében töltessenek ki egy általunk elöre összeállított kérdöivet a környezetükben élő olyan felnőtt személyekkel, akik az elmúlt öt évben jártak valamelyik előre megadott mediterrán országban. A megkérdezettek válaszai kizárólag az általuk megjelölt államra vonatkoztak (Spanyolország 53, Görögország 75, Olaszország 91 kérdöív). Összesen 219 kérdöív került kiértékelésre, amelynek eredményei - elsỏsorban a számos nyílt kérdésre adott válaszok feldolgozása során szerzett tapasztalatok révén - elősegítették a turisztikai miliöröl meglévő ismereteink kibővítését. A véletlenszerüen megkérdezettek 41\%-a 18-24, 34\%-a 25-40 év közötti, 25\%-a pedig 60 év feletti, 38\%-a tanuló, 62\%-a munkavállaló volt, lakóhelyük földrajzi kiterjedése a székesfehérvári (16\%) és budapesti (25\%) koncentráció mellett Magyarország összes megyéjét érintette. A vizsgált probléma szempontjából a mediterrán térség a magyar lakosság viszonylatában is ideális kutatási terepnek tekinthető, mivel a hazai utazási szokásokról szóló felmérések tanúbizonysága szerint (M.Á.S.T. 2004) Spanyolország, Görögország és Olaszország évek óta a legkedveltebb célterületek közé tartoznak.

A mediterrán kifejezés értelmezését tekintve a földrajztudományban a geopolitikai és az éghajlattani megközelítés a legelterjedtebb. Előbbi az ENSZ aktuális besorolása ${ }^{14}$ szerint magában foglalja mindazokat az európai, afrikai és ázsiai országokat, amelyek a Földközi-tenger medencéje mentén fekszenek, utóbbi a mérsékelt éghajlati övezetben jellemzően a kontinensek nyugati oldalán kialakult nyáron forró, száraz, télen hüvös, csapadékos éghajlati tartományt jelöli (Péczely 1984; 
Hevesi 1997). Természetesen a két kategória csak szük terjedelemben fedi egymást, mivel a geopolitikai értelemben vett mediterrán térségben elhelyezkedő, elsősorban észak-afrikai (Algéria, Marokkó, Tunézia, Libanon, Egyiptom) országok területe sokkal inkább a forró övezetbe, míg a közel-keletieké (Izrael, Libanon, Szíria) és Törökországé a mérsékelt övezet száraz kontinentális tartományába esik, arról nem is beszélve, hogy mediterrán éghajlattal az amerikai és az ausztrál kontinensen is találkozhatunk. Annak ellenére, hogy a turizmuspolitikai értelemben vett mediterrán országok sem szorítkoznak Európára (WTO 1997), a mediterrán turisztikai miliö mibenlétének feltárása és értelmezése kapcsán nem lépünk túl az európai kontinens Földközi-tenger környezetében fekvő államain (Portugália, Spanyolország, Franciaország, Monaco, Olaszország, San Marino, Málta, Horvátország, Szlovénia, BoszniaHercegovina, Makedónia, Szerbia-Montenegró, Albánia, Görögország, Ciprus).

\section{A mediterrán turisztikai miliő elemei az asszociációkban}

Tekintettel arra, hogy a mediterrán turisztikai miliő feltárásához elengedhetetlen az azonos tartalmú miliőelemek különböző országok vonatkozásában történő tettenérése, ezért a nemzetközi turizmuskutatásban is ismert (Michalkó-Minca 2000) egyszerủ asszociációs kérdésfeltevéssel igyekeztünk a problémához közelebb kerülni. Egy-egy országról a fejekben élö gondolatok asszociatív lehívása elősegítheti a közös miliöelemek megragadását, igaz, ha azokat bármilyen okból elnyomják a kognitív tényezők, akkor más módszerrel kell a nehezen megragadható turisztikai miliő képét összeállítani. Ennek a módszernek a gyengesége tehát abban rejlik, hogy a korábbiakban felvázolt miliőelemekre vonatkozó képzettársítás az eredeti környezetböl származó ingerek kopása, elmaradása miatt irrelevánssá válhat.

\section{TÁBLÁZAT}

A legfontosabb képzettársitások néhány mediterrán ország vonatkozásában (The Most Important Idea Associations in Respect of Some Mediterranean Country)

\begin{tabular}{clcclcclcc}
\hline Hely & $\begin{array}{c}\text { Gondolatkör } \\
(N=91)\end{array}$ & Olasz* & Hely & $\begin{array}{c}\text { Gondolatkör } \\
(N=75)\end{array}$ & Görög* & Hely & $\begin{array}{c}\text { Gondolatkör } \\
(N=53)\end{array}$ & Spanyol* \\
\hline 1. & Gasztronómia & 20,4 & 1. & Gasztronómia & 19,8 & 1. & Tenger & 16,5 \\
2. & Táj & 18,4 & 2. & Tenger & 17,0 & 2. & Bikaviadal & 13,5 \\
3. & Tenger & 10,9 & 3. & Táj & 12,5 & 3. & Gasztronómia & 13,1 \\
4. & Ember & 7,7 & 4. & Müemlék & 9,5 & 4. & Tánc & 10,4 \\
5. & Müemlék & 6,1 & 5. & Történelem & 8,1 & 5. & Éghajlat & 8,8 \\
6. & Történelem & 5,9 & 6. & Sport & 7,0 & 6. & Táj & 7,3 \\
7. & Nyüzsgés & 5,2 & 7. & Atmoszféra & 5,8 & 7. & Ember & 6,9 \\
8. & Éghajlat & 5,0 & 8. & Éghajlat & 5,6 & 8. & Történelem & 5,4 \\
9. & Zene & 4,5 & 9. & Ember & 4,5 & 9. & Atmoszféra & 4,6 \\
10. & Sport & 3,4 & 10. & Zene & 4,5 & 10. & Nyüzsgés & 4,2 \\
\hline
\end{tabular}

Megjegyzés: *megoszlás az összes százalékában.

Forrás: Saját adatgyüjtés (2004). 
Olasz-, Görög- és Spanyolország vonatkozásában a megkérdezettek első öt, többnyire kulcsszavakban közölt gondolatait súlyozás nélkül 71 asszociációs csoportba soroltuk. Az egyes országokra jellemzö csoportokat a megoszlásuk százalékos nagyságrendje szerint sorrendbe állítottuk és az 1. táblázatban közreadtuk. Mindhárom mediterrán ország viszonylatában az első tíz gondolat között található a gasztronómia, a táj, a tenger, az ott élö emberek, a történelem és az éghajlat valamilyen asszociációja, külön aláhúzandó, hogy a gasztronómia és a tenger minden esetben az elsö három hely valamelyikén szerepel. A közös miliỏelemek kiemelése érdekében e helyen nem tudunk hangsúlyt helyezni a mindössze egy vagy két országot jellemzö gondolatokra, azonban nem szabad elmennünk az érdemi mértékben kizárólag Spanyolországnál szereplő bikaviadal vagy a tánc mellett, mert ezek önmagukban is jelentősen formálják a turisztikai miliőt.

A gasztronómia magas arányú szereplése - függetlenül az eltérő receptura alapján készült ételek és italok egyedi mivoltától - egyértelmủen a mediterrán ízvilág elsődlegességét tükrözi a miliöelemek csoportjában. Az ételek közül az olasz pizza és tésztafélék, a görögsaláta vagy a spanyol paella egytöl egyig a paradicsom, az olíva olaj és a fokhagyma/hagyma kombinációján alapszik. A tenger gyümölcseiböl, halakból, bárányhúsból készuilt ételek és a vörösborok szintén domináltak az elsö gondolatok között. A gasztronómia természetesen szoros összefüggésben áll az országok földközi-tenger parti fekvésével, így nem meglepö, hogy a tengerhez kapcsolódó asszociációk szintén az elsök között szerepeltek. Az ide sorolt válaszok között magával a tenger fogalmával találkozhattunk a legtöbb alkalommal, de a homokos part, a vízi sportok és a hajózás is gyakran elöfordult. A mediterrán országokban élő emberekkel, mint vendéglátókkal kapcsolatban a vendégszeretet, a gondtalan élet, a szenvedély, a lazaság, a pozitív kedélyállapot, a mosolygás és a sajátos temperamentum voltak a leginkább szerepeltetett fogalmak. Meg kell, jegyezzük, hogy a „4 S”-ként (sun, sea, sand, sex) aposztrofált turizmusban megjelenő „sex” - amit a magunk részéröl lazább erkölcsi életmódként értelmezünk (Michalkó 2004) - is előkerült méghozzá a jóképú, vonzó férfiak és a flört megnevezéssel. Vizsgálatunk szempontjából talán a táj a legproblematikusabb kategória. mivel itt kerültek feltüntetésre a megkérdezettek által megjelölt (a konkrét településeken kívüli) földrajzi nevek, amelyek között lagúnákkal, vulkánokkal, tavakkal, hegyekkel és szigetekkel egyaránt találkozhattunk. Az éghajlat ebben az esetben is megkerülhetetlen turisztikai miliőelemnek mutatkozik, mivel a magyarországihoz képest sokkal kiegyenlítettebb időjárási viszonyok, a folyamatos napsütés, az esőmentes időszakok hossza hatást gyakorol a tartózkodás minöségére. A történelem és vele összefüggésben a kultúra megjelenítése nem feltétlenül az általános mủveltség visszatükröződése, sokkal inkább a települések épületei, mủemlékei által sugárzott történelmi hangulat leszürődése. Ezt az is alátámasztja, hogy itt a gondolatok között a konkrét építmények, müalkotások vagy alkotókkal szemben általában az ókor, a középkor, a képzỏmủvészet és a múzeum kifejezések olvashatók.

Összefoglalva megállapítható, hogy az első gondolatok között ugyan leszürhető a mediterrán turisztikai miliö mibenléte, de a fizikailag is testet öltő attrakciókhoz 
képest a miliỏelemek szerepeltetése kisebb mértékủ. Mint már említettük, a rögzítés érdekében mentálisan is feldolgozandó ingerek az idỏ múlásával elhal ványodnak, helyüket a tárgyiasult világ tényezői foglalják el. Azonban bizakodásra adhat okot, hogy olyan miliöelemek, mint a nyüzsgés vagy az atmoszféra, ha nem is mindhárom országnál és nem is az első helyek valamelyikén, de előkerültek. A nyüzsgés sajátos szinonimáiként szerepeltették a tömeget, a hangzavart, a gyorsaságot, a robogók világát és az éjszakai élet lüktetését. Az atmoszféra erős mozaikosságot mutatott a színeket illetően, az élénkség és a kizárólag Görögországot jellemző kékfehér színösszeállítás került elö, e mellett - feltehetöen a növényzettel összefüggésben - a zöld domborodik a válaszok közül ki.

\section{A mediterrán kultúrtáj}

A mediterrán táj elemeinek körülírása a domborzat és az éghajlat determinizmusából fakadóan egy átlagos mủveltségủ ember számára nem jelenthet akadályt. Ha valaki soha életében nem járt Dél-Európa valamelyik országában, tanulmányai alapján akkor is fel tudja idézni a táj azon jellegzetességeit, amelyek az olaj- és szelídgesztenyefák, törpepálmák, cédrusok, a macchia-vidékek, kiszáradt folyómedrek, helyenként kopár sziklák együtteséböl fakadnak (Chevalier 2001). A turisztikai miliö szempontjábół azonban a tájnak az emberi beavatkozás következtében létrejövő arculatát, vagyis a kultúrtájat kell figyelembe venni. Ha végignézzük az elektronikus médiaforradalom előtti korszak vizuális nagyköveteinek, azaz a festỏmüvészeknek az alkotásait, akkor láthatjuk, hogy az esetek többségében a mediterrán tájban megjelenik a társadalmi produktum. Az itáliai barokk festészetet képviselö Canaletto $^{15}$, vagy a magyar posztimpresszionista Csontváry ${ }^{16}$ számos al kotása füződik a mediterrán kultúrtájhoz.

A települések szerkezete, arculata a táj és a társadalmi tevékenység szimbiózisának egyfajta tükörképe (Beluszky 1999). De vajon léteznek-e az adott tájat szimbolizáló települések, beszélhetünk-e tipikus mediterrán településröl, és ha igen, akkor meghatározható-e, hogy milyen tájelemeket kellene magán hordoznia? A jelen tanulmány terjedelmi korlátaira való tekintettel a problémát kizárólag a turizmus szempontjából igyekszünk exponálni, így a megkérdezettek válaszai alapján az adott országot leginkább jellemzö település kiemelése mellett a turistaút alapján rögzült tipikus tájelemek előhívását végezzük el. A vizsgálatba vont három mediterrán ország kapcsán összesen 56 jellegzetes település került megnevezésre, a falvak és a városok aránya az utóbbiak előnyére tolódott el, de Görögország kapcsán számos szigetet is említettek a megkérdezettek. A válaszok száma alapján legtipikusabbnak nevezett spanyol település Barcelona (36\%), Olaszország kapcsán Velence (25\%), Görögország esetében pedig Athén (53\%). Tekintettel arra, hogy az eredményt nyilvánvalóan befolyásolta az adott települést meglátogatók száma, a közlekedés-földrajzi helyzete és a telepưlési térben megtalálható versenytársak jelenléte, az eredményböl messzemenő következtetést nem szabad levonni. Annyit azonban érdemes megjegyezni, hogy az említett nagyvárosok a tengerparti fekvésüknek, a 
turistaforgalomból fakadó kavalkádjuknak, a történelmet sugárzó kulturális intézményeiknek, épületeiknek és müemlékeiknek, a lépten-nyomon tetten érhetö gasztronómiai kínálatnak, továbbá az ott élő lakosság nyitottságának köszönhetỏen kétségtelenül alkalmasak a mediterrán turisztikai miliő elemeinek számbavételére.

\section{TÁBLÁZAT}

A leggyakoribb telepiilésképi elemek néhány mediterrán ország vonatkozásában (The Most Frequent Settlement Pictures in Respect of Some Mediterranean Country)

\begin{tabular}{lccc}
\hline \multirow{2}{*}{\begin{tabular}{l} 
Elemek \\
\cline { 2 - 4 }
\end{tabular}} & $\begin{array}{c}\text { Olasz } \\
(N=91)\end{array}$ & $\begin{array}{c}\text { Görög } \\
(N=75)\end{array}$ & $\begin{array}{c}\text { Spanyol } \\
(N=53)\end{array}$ \\
\hline Templom, kolostor & 6,2 & 5,2 & 5,6 \\
Hétköznapi életképek & 12,3 & 5,2 & 4,0 \\
(szociális helyzetek) & 14,5 & 14,9 & 11,1 \\
Sikátor & 15,1 & 19,7 & 28,4 \\
Tengerpart, pálmafa & 16,3 & 25,8 & 16,5 \\
Történelmi korokat idézó épület & 16,8 & 14,4 & 15,1 \\
Szálloda, vendéglö, kávéház, & 17,9 & 13,2 & 15,9 \\
kis üzlet & 0,9 & 1,6 & 3,4 \\
Szobor, szökökút & & & \\
Egyéb &
\end{tabular}

Forrás: Saját adatgyüjtés (2004).

A megkérdezetteknek az adott ország egy tipikus településére vonatkozó kognitív térképe számos olyan elemet tartalmaz, amely a másik kettỏ esetében is felidézésre került (2. táblázat). Annak ellenére, hogy az egyes mediterrán országok tipikus települését jellemző tájelemek megoszlása nem minden esetben mutat azonos nagyságrendet, mégis az említettek összes tájelemen belüli szinte 100\%-os részesedése egyértelmüen igazolja a mediterrán kultúrtáj fogalmának turisztikailag releváns létezését. A másodlagos szuprastruktúra (szálloda, vendéglö, kávéház, kis üzlet) külön megjelenítése hozzájárul a turisztikai miliö pontosabb kirajzolásához, mert feltehetően a hozzájuk füzödő pozitív életérzések, a szolgáltatás körülményeivel való elégedettség segíti elö a stabil rögzülésüket. Az egyes elemek részesedésénél jelentkező számottevő differencia kialakulásában értelemszerüen az adott ország sajátosságai vesznek részt, így pl. az olyan hétköznapi életképek, mint a mosás után az utcán száradó ruhák vagy a robogózó fiatalok között zajló társadalmi élet inkább az olaszokat jellemzi. A történelmi épületek görög, illetve a tengerpart, pálmafa tájelem spanyol dominanciája összefüggésbe hozható Athén és Barcelona korábbi kiemelésével vagy az adott országban végzett elsődleges turisztikai tevékenységgel.

\section{Társadalmi helyzetek a mediterrán turisztikai miliöben}

A sztereotípia-kutatás egyik szakterülete, a nemzetkarakteorológia kapcsán korábban napvilágot látott, hogy számos magyar (Rónay Jácint, Szekfü Gyula, Cholnoky Jenő, Mendöl Tibor) és külföldi gondolkodó (Hugo Münsterberg, Kent 
Lewin) próbálkozott az egyes népek jellemzöinek leírásával (Cholnoky 1936; Mendöl 1949; Szekfü 1989; Hunyady 2003). Ezen munkák többsége a műveltség, a nemzeti nyelv, az éghajlattal összefüggő termelési hagyomány és életmód, a táplálkozás és a mindennapi szokások felöl közelítették a tárgyalt népeket. A sztereotípiák közismerten stabilak és meghatározzák a közgondolkodást (Hunyady 1996; Csepeli 2003), azonban legfeljebb a turisztikai imázs, semmi esetre sem a miliő alkotóelemeiként jöhetnek számba. A mediterrán turisztikai miliö leírása során a turista által megélhető tipikus élethelyzetek értékelését tartjuk célravezetőnek, ebből kirajzolódik az ott élő társadalom néhány tipikusnak tekinthető jellemvonása.

\section{TÁBLÁZAT}

Az áruvásárlás és a vendéglátó-ipari szolgáltatás társadalmi vetületeiben észlelt eltérések néhány mediterrán ország vonatkozásában

(The Observed Differences in the Social Dimension of Purchasing and Catering Trade Service in Respect of Some Mediterranean Country)

\begin{tabular}{ccccc}
\hline \multirow{2}{*}{ Eltérés } & \multirow{2}{*}{ Szituáció } & \multicolumn{3}{c}{ Megoszlás $(\%)$} \\
& & $\begin{array}{c}\text { Spanyol } \\
(N=53)\end{array}$ & $\begin{array}{c}\text { Görög } \\
(N=75)\end{array}$ & $\begin{array}{c}\text { Olasz } \\
(N=91)\end{array}$ \\
\hline \multirow{2}{*}{ Nincs különbség } & Áruvásárlás & 24,5 & 13,3 & 25,3 \\
& Vendéglátás & 46,3 & 42,9 & 41,8 \\
Pozitiv töltetủ különbség & Áruvásárlás & 39,6 & 45,3 & 44,0 \\
& Vendéglátás & 38,9 & 37,7 & 37,7 \\
Negatív töltetủ különbség & Áruvásárlás & 5,7 & 12,0 & 18,7 \\
A probléma szempontjából & Vendéglátás & 3,4 & 2,4 & 5,5 \\
irreleváns különbség & Áruvásárlás & 30,2 & 29,3 & 12,1 \\
& Vendéglátás & 11,4 & 17,0 & 15,0 \\
\hline
\end{tabular}

Forrás: Saját adatgyűjtés (2004).

A turisztikai tevékenység során a vendéglátó-ipari egységek igénybevétele és az áruvásárlás tekinthető a helyi társadalommal szorosabb kapcsolatba kerülés klasszikus terepének (ismert persze, hogy az üdülömunkások számának növekedése némileg árnyalhatja ezt a képet [Michalkó-Berényi-Illés 2003]). Amikor a megkérdezetteknek az adott országban tapasztalt áruvásárlási körülményekről kellett nyilatkozniuk, akkor a válaszadók közel fele nem magára az árura, annak árára, minőségére vagy választékára koncentrált (ezt a kiértékeléskor irrelevánsnak tekintettük), hanem az értékesítés szituációjának sajátos társadalmi, emberi vetületeit emelte ki. Mindhárom mediterrán ország esetében a vásárláskor tapasztalt életérzések pozitív tartalma jelentös mértékben meghaladja a negatívat. A gyors és kedves kiszolgálás, a vásárlás kellemes hangulata, az alkudozás és az esti vásárlás lehetősége nagyságrendekkel szemben áll a lassú és barátságtalan kiszolgálás mérhetỏ tényével. Valamely vendéglátó-ipari egységben elfogyasztott emlékezetes (fö)étkezés jellegzetes körülményei emberi oldalának feltárása egy szimpla vásárláshoz képest összetettebb kérdésnek számít, mivel a szolgáltatás igénybevételének időtartama hosszabb, tényezöi sokrétủbbek. Feltehetően ennek köszönhető, hogy a megkérdezettek több tényezöt együttesen mérlegelve mondták, hogy a vásárláshoz képest kevesebb 
különbség észlelhetö. Az azonban fïgyelemre méltó, hogy ebben a szegmensben is a pozitív tapasztalatok kerekedtek felül, azaz a kedves kiszolgálás, a gyorsaság, a tisztaság, az ízléses tálalás és a hangulatos zene vagy tánc áll szemben a nyelveket nem beszélö pincérekkel, a lassúsággal, a hangzavarral és a higiénia hiányával. Ebben a kérdésben irrelevánsnak tekintettük az adagok nagyságát, az ételek ízletességét és az egyéb vendéglátó-ipari fogásokat.

\section{A mediterrán turisztikai miliö elemeinek értékelése}

Ahhoz, hogy a mediterrán térség turisztikai miliöjét egzakt mutatók segítségével tudjuk körülírni, a megkérdezettek körében előre megadott kategóriák fontosságának numerikus értékelésére került sor. Azon a skálán, ahol az 1 az egyáltalán nem jellemzőt, az 5 a jelentős mértékben meghatározót jelentette, 10 olyan miliőelemet tudtunk kiemelni, amely mindhárom ország viszonylatában meghaladta a középértéket (2. ábra).

\section{2. ÁBRA}

Az egyes miliöelemek súlya néhány mediterrán ország vonatkozásában ( $1=$ egyáltalán nem jellemzö; $5=$ meghatározó mértékben jellemzö)

(The Weight of the Individual Milieu Elements in Respect of Some Mediterranean Country)

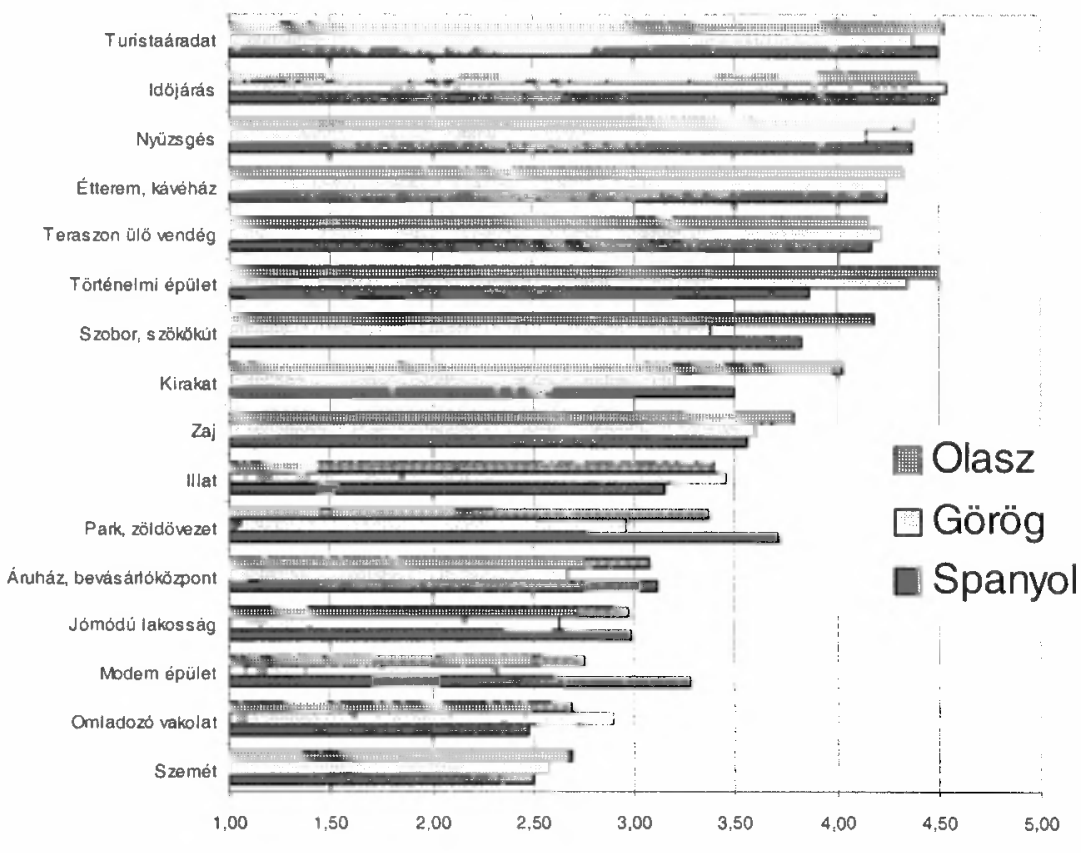

Forrás: Saját adatgyüjtés (2004). 
A vizsgált mediterrán országok vonatkozásában a turistaáradat, az időjárás, a nyüzsgés, az éttermek, kávéházak világa és a teraszon ülő vendégek látványa kapta a legmagasabb értéket. Ebből következöen megállapítható, hogy a mediterrán térségben az éghajlati tartományhoz való tartozásból fakadó kedvező időjárási viszonyok és a turisták jelenlététöl lüktető, az egymás sarkába érő vendéglátó-ipari egységektől roskadozó közterületek képe a legmeghatározóbb miliöformáló tényezỏk. A térséget legkevésbé jellemző miliőelemeknek a modern épületek, a jómódú helyi lakosság látványa és az áruházakban, bevásárlóközpontokban testet öltő kiskereskedelem tekinthetö.

\section{Összegzés}

A miliőnek, mint a társadalmi lét formálásában részt vevỏ tényezőnek a funkciója a 18. századtól foglalkoztatta a gondolkodókat. A miliő kezdetben a filozófia, majd az irodalom, később a szociológia, napjainkban a tudományok egyre szélesedő körében elterjedt multidiszciplináris fogalomnak számít. A turizmusban betöltött szerepének komplex feltárása a turizmuselmélet egyik hiátusának tekinthető. Miközben az egyes desztinációk értékelésénél a miliő különböző tényezőit számításba vesszük, együttes értékelésére ritkán kerül sor. A turisztikai miliő nem tekinthető térreleváns fogalomnak, mivel a legkisebb szolgáltatóegységtől régiókon keresztül akár kontinenseken átívelö hatókörre terjed ki. A turisztikai miliö egy mozaikos, kaleidoszkópszerü fogalom, a különbơző térségekben eltérő súllyal szerepelnek az egyes miliỏalkotó elemek, így általános érvényủen nem lehet sorrendet állítani abban a tekintetben, hogy az éghajlati sajátosságoktól a közlekedési morálig mely tényezők szerepét kell kihangsúlyozni. A Kodolányi János Fỏiskolán végzett felmérés egyrészt igazolta, hogy a tudományos kutatás tárgyává tehetö egy célállomás miliőjének leírása, másrészt turizmuselméletileg értelmezhetö a mediterrán miliő megnevezés. Az elkơvetkezendő évek turizmuskutatásaiban sokkal nagyobb hangsúlyt kell helyezni a miliővel kapcsolatos ismeretek bỏvítésére, mivel ez az első látásra nehezen megfogható kínálati elem nagymértékben befolyásolja az egyes térségek versenyképességét.

\section{Jegyzetek}

1 A tanulmányban közreadott ismeretek a „Magyarország modern turizmusföldrajza” címü OTKA (T 046074) kutatási program keretében kerültek feltárásra.

2 Montesquieu, Charles-Louis de Secondat (1689-1755), francia

${ }^{3}$ Comte, Auguste (1798-1857), francia

4 Taine, Hippolyte (1828-1893), francia

5 Durkheim, Émile (1858-1917), francia

${ }^{6}$ Scheler, Max (1874-1928), német

${ }^{7}$ Gurwitsch, Aron (1901-1973), német

${ }^{8}$ Deleuze, Gilles (1925-1995), francia

${ }^{9}$ Ritter, Carl (1779-1859), német 
${ }^{10}$ A determinizmus filozófiai elméletének megalapozásában meghatározó szerepe volt Laplace, PierreSimon de francia csillagásznak (1749-1827), aki a Naprendszer stabilitásával kapcsolutos kutatásainak eredőjeként matematikailag kívánta megjósolni a természetben elöforduló jelenségek bizonyos valószínüségeit.

11 Ratzel, Friedrich (1844-1904), német

12 Dékány István (1886-1965), magyar

${ }^{13}$ Mendöl Tibor (1905-1966), magyar

14 www.un.org

${ }^{15}$ Canaletto, Giovanni Antonio Canal (1697-1768), olasz

${ }^{16}$ Csontváry, Kosztka Mihály Tivadar (1853-1919), magyar

\section{Irodalom}

Beluszky P. (1999) Magyarország településfoldrajza: általínos rész. Dialóg Campus Kiadó. BudapestPécs.

Berényi I. (2001) Kultúrtáj-kutatás európai dimenzióban. A földrajz eredményei az új évezred küszöbén. Magyar Földrajzi Konferencia. Szeged. CD ROM

Chevalier, M. (2001) La Géographie et les peintres: La France méditerranéenne (1860-1950). - La Geographie: Acta Geographica. 173. 44-62. o.

Cholnoky J. (1936) A Föld és Élete: Világrészek, orszägrészek, emberek. I. kötet (Európa). Franklin Társulat, Budapest.

Clark, A.N. (ed.) (1985) Longman Dictionary of Geography - human and physical. Longman, Essex.

Csepeli Gy. (2003) Szociálpszichológia. Osiris Kiadó, Budapest.

Csíkszentmihályi M. (1998) És addig éltek, amíg meg nem haltak: a mindennapok minösége. Kulturtrade, Budapest.

Dékány 1. (1921) Milieu-elmélet, kulturföldrajz és a mai szociológia. - Föld és Ember. 1. 40-50. o.

Dövényi Z.-Kováes Z. (1999) A szuburbanizáció térbeni-társadalni jellemzöi Budapest környékén. Földrajzi Értesítö. 1-2. 33-57. o.

Durkheim. E. (1978) A társadalmi ténvek magvarázatához. Közgazdasági és Jogi Kiadó. Budapest.

Embree, L. (2003) Aron Gurwitsch's Theory of Cultural-Scientific Phenomenological Psychology. Husserl Studies, 1. 43-70. o.

Erdösi F. (2003a) Globalizáció és a világvárosok által urult tér. - Têr ếs Társadalom. 3. 1-27. o.

Erdösi F. (2003b) Globalizáció és a világvárosok által uralt tér II. - Tér és Társadalom. 4. 1-16. o.

Fischer, K.-Parnreiter, C. (2002) Transformation und neu Formen der Segregation in den Städten Lateinamerikas. - Geographica Helvetica. 4. 245-252. o.

Fülemile Á. (1998) A skót nemzeti viselet és Skócia turisztikai képe. - Fejös Z. (szerk.) A turizmus mint kulturális rendszer. Néprajzi Múzeum, Budapest. 57-74, o.

Gehlen, A. (1976) Az ember természete és helye a világban. Gondolat, Budapest.

Hajdú Z. (1998) Friedrich Ratzel hatása a magyar földrajztudományban. - Tér és Társadalom. 3. 93-104. o.

Hevesi A. (1997) Természetföldrajzi Kislexikon. PannonKlett Könyvkiadó, Budapest.

Hradil, S. (1994) Régi fogalmak és új struktúrák. Miliö-, szubkultúra- és életstílus-kutatás a 80-as években. - Andorka R.-Hradil, S.-Peschar J. (szerk.) Társalalmi rétegzódés. Aula, Budapest. 347-387. o.

Hunyady Gy. (1996) Sztereotípiák a változó közgondolkodásban. Akadémiai Kiadó, Budapest.

Hunyady Gy. (szerk.) (2003) Nemzetkarakterológiäk: Rónay Jácint, Hugo Münsterberg és Kurt Lewin irásai. Osiris, Budapest.

Illés S. (2000) Belföldi vándormozgalom a XX. század utolsó évtizedeiben. KSH Népességtudományi Kutatóintézet, Budapest.

Kirk, W. (1963) Problems of geography. - Geography. 3. 357-371. o.

Kozma T. (2001) Bevezetés a nevelésszociológiába. Nemzeti Tankönyvkiadó, Budapest.

M.Á.S.T. (2004) A magyar lakosság külföldi utazásai. M.Á.S.T. Piac- és Közvéleménykutató Társaság. - Turizmus Bulletin. 2. 3-10. o.

Maslow, A. (2003) A lét pszichológiája felé. Ursus Libris, Budapest.

Mayhew, S. (1997) Oxford dictionary of geography. Oxford University Press, Ox ford.

Mendöl T. (1932) Táj és ember. Az emberföldrajzáttekintése. Magyar Szemle Társaság, Budapest.

Mendöl T. (1949) Általános emberföldrajz. Pázmány Péter Tudományegyetem BTK, Budapest. Jegyzet.

Meyer, G. (2001) Revitalisierung der Innenstadt von Jena. - Geographische Rundschau. 3. 24-30. o. 
Michalkó G.-Berényi I.--Illés S. (2003) Adalékok a turizmus és migráció kapcsolatának elméleti megközelítéséhez. - Tér és Társadalom. 4. 51-65. o.

Michalkó, G.-Minca, C (2000) L'immagine turistica dell' Italia in Ungheria. - Turistica. 9. 17-32. o.

Michalkó G. (2004) A turizmuselmélet alapjai. Kodolányi János Főiskola, Székesfehérvár.

Moldvay T. (1997) Deleuze és a filozófia. Metropolis. 2. 17-31. o.

Péczely Gy. (1984) A Föld éghajlata. Tankönyvkiadó, Budapest.

Phillips, M. (1993) Rural gentrification and the processes of class colonization. - Journal of Rural Studies. 2. 123-140. o.

Pizam, A.-Sussmann, S. (1995) Does Nationality Affect Tourist Behavior? - Annals of Tourism Research. 4. 901-917. o.

Pritchard, A.-Morgan, N. (2001) Culture, identity and tourism representation: marketing Cymru or Wales. - Tourism Management. 2. 167-179. o.

Puczkó L.-Rátz T. (1998) A turizmus hatásai. Aula Kiadó, Budapest.

Ratzel, F. (1887) A Föld és az ember. Anthropo-geographia vagy a foldrajz történeti alkalmazásának alapvonalai. Magyar Tudományos Akadémia, Budapest.

Róbert P. (2000) Az életstílus meghatározottságának változása, 1982-1998. - Szociológiai Szemle. 2. 17-37. 0 .

Rókusfalvy P. (2000) Mi a környezetpszichológia? 1. - Új Pedagógiai Szemle. 4. 42-51. o.

Ryan, C. (1998) Saltwater Crocodiles as Tourist Attractions. - Journal of Suistanable Tourism. 4. 314-327. o.

Scheler, M. (1999) Az ember helye a kozmoszban. - Bujdosó D. (szerk.) Német kultúraelméleti tanul. mányak III. Nemzeti Tankönyvkiadó, Budapest. 92-105. o.

Shklar, J.N. (1994) Montesquieu. Atlantisz Könyvkiadó, Budapest.

Small, J.-Witherick, M. (1989) A Modern Dictionary of Geography. Edward Arnold, New York.

Szarvas Zs. (1998) „Valóság” és valóság. Finn turisták Magyarország képe. - Fejös Z. (szerk.) A turizmus mint kulturális rendszer. Néprajzi Múzeum, Budapest. 145-149. o.

Szekfü Gy. (1989) (Reprint) Härom nemzedék és cumi utina következik. ÁKV-Maecenas. Budapest.

Szijârtó Zs. (2004) Színpad és kulissza. - Magyar Tudonány. 10. 1164-1172. o.

Taine, H. (1881) Az angol irodalom története 1. Magyar Tudományos Akadémia, Budapest.

Vinkovics M. (1983) Carl Ritter geográfíajának ontológiai alapjai. - Földrajzi Közlemények. 2. 121-129. o.

Warren-Gash, C.-Zeman, A. (2003) Deja vu. - Practical Neurology. 2. 106-109. o.

WTO (1997) Marketing the Mediterranean as a Region Interministerial Tourism Conference: Sliema, Malta, 7-9 November 1996. WTO, Madrid.

Zsigmond L. (1984) Auguste Comte: A XIX. század politikai gondolkodásának történetéböl. Akadémiai Kiadó, Budapest.

\section{THE TOURIST MILIEU: AN GEOGRAPHICAL APPROACH}

\section{GÁBOR MICHALKÓ}

Although the milieu of a tourism destination is clearly an essential component of its attractiveness, the concept of the tourist milieu has remained a relatively under-represented notion in tourism research. We believe that the tourist milieu may be defined as the objective projection of the subjectively experienced tourist space; it emerges as individual visitor perceptions are integrated at a higher level of societal consciousness. Consequently, the tourist milieu of a destination is based on an informative consensus that reflects the visitors' emotions and impressions. In this paper summarises the key factors contributing to the development of a destination's successfully marketable tourist milieu. The study aims to analyse the objectification process of subjective visitor perceptions through which the perceived image becomes a component of social awareness. The hierarchical relationships of milieu, image, sense of place and local identity are also assessed, with particular emphasis on the role of visitor involvement and experience in theory formulation. In order to investigate and show the notion and the perceived components of the Mediterranean milieu, a qualitative survey was carried out with 219 respondents in Hungary in 2004. 